\title{
Contributing to the debate on learning in the post-2015 education and development agenda
}

\author{
Clementina Acedo
}

Published online: 19 October 2013

(C) UNESCO IBE 2013

I am pleased to introduce this issue of Prospects, the second non-thematic collection of peer-reviewed articles that we are publishing in 2013. Included in this issue are articles that bear on the complexity of the current educational landscape, with critical topics ranging from education assessments and teacher quality to the role that universities can play in peacebuilding.

The issue comes out at an especially important moment for policy, when we need to take action to ensure that education has a central place in the new development goals after 2015. Education is still considered to be "one of the most spectacular success stories of the MDG framework" (UNESCO 2012), as some of the poorest countries have made great strides in enrollment rates and gender equality. Yet, as a new report (UNESCO 2013) shows, progress towards universal primary education is stagnating, while international aid to basic education has fallen for the first time since 2002. As we approach the 2015 deadline to achieve universal primary education, 57 million children remain out of school. Among other issues, the quality of education, teacher training, curriculum development, gender equality, and student achievement remain as pertinent as ever and they must continue to be prioritized.

Now is also the right moment to re-think the international development agenda. There is an urgent need to return to fundamental questions about the aims and purposes of education and to a more holistic, integrated, and humanistic vision of learning. Education cannot be reduced to internationally agreed-upon goals and targets to be measured. Instead, education policies need to focus on learning that is relevant, and look at curriculum development as a social, cultural, and political process. They need to consider how students can most effectively acquire foundational skills and transferable competences, and how to make learning relevant for individuals, for their families and communities, and for society at large (UNESCO IBE 2013b).

The quality of education should remain a paramount concern within EFA goals and become a priority of all global and national development efforts. Yet, quality education

C. Acedo $(\bowtie)$

UNESCO International Bureau of Education, Geneva, Switzerland

e-mail: c.acedo@unesco.org 
cannot be achieved without the crucial contribution of good teachers. Preparing and retaining good teachers should remain a central policy concern for all countries, which need to develop comprehensive policies to improve the quality of the teaching force, as well as teachers' status, pay levels, and working conditions.

Curriculum too is at the heart of quality education. It is also a vital foundation for learning-related educational reforms. For reforms to be effective, the curriculum should reflect a society's shared vision of education, "while taking into account local, national and global needs and expectations" (UNESCO IBE 2013a). As a means of implementing educational aims, the curriculum must also point the way, as educators and other actors coordinate policy and planning, prepare appropriate textbooks and other learning support resources, prepare teachers, build capacity, and assess learning.

The quality of education and access to education are closely linked. Access to basic education cannot be separated from the equitable provision of quality education. Thus, the international community needs to promote an integrated approach to inclusive quality education. The combined aim of improving learning and expanding opportunities should serve as the anchor for our educational targets, as we aim for equitable access to relevant and effective learning for all (UNESCO IBE 2013b).

The International Bureau of Education is deeply engaged with these issues. Likewise, Prospects continues to publish articles on emerging topics that attract new attention from educators. We hope that our work can influence education debates and contribute to the reshaping of the international development agenda after 2015.

The articles gathered in this issue add substantive arguments to ongoing scholarly debates, by critiquing the "abuses" of education assessments, comparing teacher certification and student achievement in various contexts, exploring the financial burden of attending university and its implications for rural students, considering the educational disadvantages that indigenous women face, analyzing how universities in conflict zones contribute to development, examining the actual practices of inclusive education, and highlighting the role that mentoring, peer counseling, and parental involvement can play in student achievement.

The Viewpoint authored by Simon Schwartzman is a plea for moderation when using external assessments and quantitative measurements. Taking Brazil as an example, he argues that indicators are "precarious and simplified representations of much more complex realities". Behind the numbers lie the multifaceted contexts of each locality and school, which need to be taken into account in order to build "good education institutions".

Not letting assessment procedures take on lives of their own is also suggested by Alexander Weisman and Fawziah Al-bakr in their comparative analysis of teacher certification and student achievement in the Gulf Cooperation Council (GCC) countries. Many countries in the Gulf area are actively seeking to measure teacher quality through teacher certification, and to evaluate teacher quality by using scores on student achievement tests. However, the authors did not find a strong correlation between certification and teachers' ability to teach. Nor did they find that high student achievement was correlated with high teacher scores on national and international exams or with high-quality teachers' certification. Instead, they confirmed that characteristics related to students' socioeconomic status and to teachers' ability to teach play an important role in student achievement. They conclude their article by reiterating the constant challenge for policymakers and educators, in the Gulf and elsewhere: to design teacher certification processes that effectively improve teacher quality.

Maya Chankseliani analyses the impact on rural students in Georgia of policies to financially support university students. Although urban and rural students incur the same 
average out-of-pocket tuition costs, she found "systematic spatial disparities" based on several factors, including the residential origin of higher education applicants, tuition costs, public funding allocations, university locations, and prestige. Each factor has a different effect on university access for students from urban and from rural backgrounds. This is, as far as we know, the first published study to investigate policies for allocating public grants for higher education in post-Soviet Georgia. We hope, along with the author, that this article will help both academics and policy-makers to identify and address inequalities in access to higher education for rural students.

Ane Turner Johnson discusses how faculty and administrators at public universities in a conflict zone can act as agents of conflict transformation and peacebuilding. She analyzes how those universities changed their internal policies and practices to accommodate students and activities impacted by the conflict. Peacebuilding, she argues, is more than "a reaction to conflict". Instead, it needs to be seen as a critical element of education systems in fragile states. This way, universities may contribute to sustainable solutions to violence in East Africa and more generally in the sub-Saharan region.

Taeko Takayanagi and Takayuki Shimomura examine the views of Ainu women on education and their life experiences in Japan, through the lens of postcolonial feminist theory. Their narratives reveal the interactions between two kinds of hardships they face: obstacles to continuing their education, and strong gender and ethnicity discrimination, especially in employment. This study, the first ever conducted in Japan that focuses exclusively on the voices of young Ainu women, is a call for action to support the voices of indigenous women. This can be done, the authors argue, by designing and implementing more vigorous anti-discrimination policies and a comprehensive policy reform for indigenous peoples.

As I noted in a previous Editorial (Acedo 2011), very little research has focused on the actual practice of inclusive education and how it can be supported by training and school contexts. The article by Michal Razer and Victor J. Friedman adds to the pool of important empirical studies on the topic, while also responding to our call for innovative research in teaching and learning processes related to inclusive education (UNESCO IBE 2008). In their study, the authors explore ways in which teachers can unintentionally abandon students emotionally. As a solution to this issue, they argue that the teaching role needs to be expanded, to include "therapeutic elements". Sensitivity to and empathy with the emotional world of the child are elements that need to be incorporated into the training and professional development of teachers and other educational professionals. This is, as the authors say, a necessary element "to make Education for All and social inclusion an integral part of their practice".

Cynthia Akorfa Sottie, Nicole Dubus, and Marie-Antoinette Sossou propose a program of mentoring, peer counseling, and parent involvement for children from first through ninth grade in Ghana. The project is a model for school partnerships with parents, peers, teachers, and other stakeholders in education, to ensure that students succeed. The article is a reminder of the positive influence that mentoring, peer counseling, and parent involvement can have on the lives of vulnerable and at-risk school children.

The articles in this issue of Prospects look at different aspects of education from various perspectives, their authors expressing concerns about a range of issues in the field. But they also share much in common, including the implicit concern that students at every level be provided with quality inclusive education. As such, this issue offers an important contribution to the current international debate about education policies, goals, and targets in the post-2015 international development agenda. 


\section{References}

Acedo, C. (2011). Preparing teachers for inclusive education. Prospects, 41(3), 301-302.

UNESCO (2012). Education for All: Beyond 2015. Mapping current international actions to define the post2015 education and development agendas. Paris: UNESCO.

UNESCO IBE [International Bureau of Education] (2008). Conclusions and recommendations of the 48th session of the International Conference on Education. Geneva: UNESCO IBE. http://www.ibe.unesco. org/en/ice/48th-ice-2008/conclusions-and-recommendations.html.

UNESCO IBE (2013a). Presentation brochure. http://www.ibe.unesco.org/fileadmin/user_upload/ Publications/Institutional_Docs/IBE_brochure_2013_eng.pdf.

UNESCO IBE (2013b). Learning in the post-2015 education and development agenda. Statement inspired by the International Experts' Meeting on "Key Curricular and Learning Issues in the Post-2015 Education and Development Agenda", UNESCO IBE, Geneva, 23-25 September 2013. http://www. ibe.unesco.org/fileadmin/user_upload/Publications/UNESCO_IBE_Statement_on_Learning_Post2015.pdf.

UNESCO \& UIS [UNESCO Institute of Statistics] (2013). Schooling for millions of children jeopardized by reductions in aid. Education for All Global Monitoring Report Policy Paper 09. Paris: UNESCO EFA/ UIS. http://unesdoc.unesco.org/images/0022/002211/221129e.pdf. 